\title{
Lepidochitona bullocki, una nueva especie de quitón (Polyplacophora: Ischnochitonidae) del Caribe colombiano
}

\section{Cedar I. García-Ríos}

Departamento de Biología, Universidad de Puerto Rico en Humacao, 100 Carr 908, Estación Postal CUH, Humacao, Puerto Rico 00791; cedar.uprh@gmail.com

Recibido 13-IX-2010. C Corregido 25-II-2011. Aceptado 28-III-2011.

\begin{abstract}
Lepidochitona bullocki, a new species of chiton (Polyplacophora: Ischnochitonidae) from the Colombian Caribbean. The genus Lepidochitona is one of the most diverse in the Southern Caribbean. In order to describe this new species, twenty specimens of L. bullocki sp. nov. were collected by hand on the rocky coast, from 0.25 to $1.5 \mathrm{~m}$ depth, and a shore distance of 1 to $5 \mathrm{~m}$, between the Northern section of Rodadero beach and Puerto Luz, in Santa Marta, Colombia. The specimens were small, with maximum observed size of 7.3mm. This is the fourth species of the genus Lepidochitona described for the Caribbean. The previously known species were L. liozonis (Dall \& Simpson 1901), L. rosea (Kaas 1972) and L. rufoi (García-Ríos 2010). L. bullocki differs from L. liozonis and L. rosea in having a rough tegmentum and color. It differs from L. rufoi in having longer and numerous hyaline spicules, bigger size and broader central radula tooth. Lepidochitona bullocki is the only Caribbean species of the genus frequently located on the illuminated side of rocks in the shallow sublitoral zone. Rev. Biol. Trop. 59 (3): 1105-1114. Epub 2011 September 01.
\end{abstract}

Key words: Mollusca, Polyplacophora, Ischnochitonidae, Lepidochitona, Caribbean, Colombia, new species.

El género Lepidochitona (Gray 1821) se encuentra representado en el Caribe por tres especies: L. liozonis (Dall \& Simpson 1901), L. rosea (Kaas 1972) y L. rufoi (García-Ríos 2010). En los registros de los quitones recuperados en dragados cerca de Isla Coche en Venezuela, (Bullock et al.1994) mencionaron una especie de Lepidochitona pequeña $(5 \mathrm{~mm}$ longitud), con el tegumento granular. Ninguno de los dos lepidoquitones descritos hasta ese entonces tienen el tegumento granuloso, por lo que concluyeron que se trataba de una especie sin describir (Bullock et al. 1994). En un trabajo relacionado, donde se incluyen las especies presentes en aguas someras en Isla Margarita en Venezuela, Bullock \& Franz (1994) mencionan y muestran fotografías de dos especies de Lepidochitona sin describir, una de ellas con tegumento granular, coloración marrón anaranjado, valvas muy arqueadas y cuerpo alargado. La otra especie sin describir, mencionada por Bullock \& Franz (1994), tiene el tegumento granular, es policromática y la encontraron en el área de embate del oleaje, entre las algas que crecen sobre las rocas, donde también se encontraban ejemplares de Acanthochitona balesae (Abbott 1954). Estos autores reconocieron como diferentes a estos dos ejemplares del mencionado en Bullock et. al. (1994). Los trabajos citados dejan establecido que el género Lepidochitona en el Caribe es más diverso y que esa mayor diversidad está en el sur, donde los trabajos de inventario y descripción han sido limitados (Gracia et al. 2005, Lyons 1988).

Durante el mes de octubre de 2009 se realizó un reconocimiento de posibles estaciones de recolección en el litoral de Santa Marta, 
Colombia, para ejecutar en el futuro un censo de quitones. El objetivo de este trabajo es describir una especie nueva de lepidoquitón que se recolectó como parte de aquel ejercicio.

\section{MATERIALES Y MÉTODOS}

Veinte ejemplares de L. bullocki fueron recolectados en un recorrido a lo largo del litoral rocoso, entre el norte de la playa del Rodadero (11²'27.3' N, 74¹3'47.2”' W)

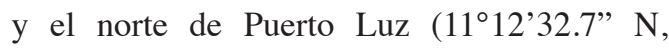
74¹4'1.3" W), en Santa Marta, Colombia. En éste se examinaron las rocas sueltas, tanto la superficie expuesta como la enterrada o en sombras, a una profundidad de 0.25 hasta $1.5 \mathrm{~m}$, y una distancia de la orilla de 1 a $5 \mathrm{~m}$. La ubicación geográfica de los ejemplares recolectados se determinó mediante la lectura de la latitud y longitud de un punto cercano al lugar de recolección, usando un GPS. Los quitones fueron relajados y aplanados para su preservación usando alcohol etílico al $70 \%$, diluido con agua destilada.

Los organismos preservados fueron examinados, medidos y fotografiados utilizando un microscopio de disección Nikon SMZ1500 con un micrómetro en el ocular. Los colores se describieron comparando los ejemplares preservados con la guía de colores de Smithe (1975). Cuatro ejemplares fueron desarticulados para su examen usando un microscopio electrónico de barrido (MEB). En estos cuatro se disolvió el tejido blando adherido a la rádula, el cinturón y las valvas con una solución caliente de KOH $2 \mathrm{~N}$ (Bullock 1985). Algunas valvas que presentaban costras sobre su superficie, fueron tratadas con ultrasonido por uno o dos minutos. Las estructuras ya limpias se lavaron con agua destilada y se almacenaron en etanol al $95 \%$.

Las estructuras seleccionadas para preparar las microfotografías, utilizando el MEB, se secaron al aire y se fijaron en bases de aluminio usando un adhesivo de carbón. Estos ejemplares se cubrieron con una película de oro usando un evaporador. La determinación de la densidad de estetos y las medidas de los elementos que recubren el cinturón se efectuaron según el método descrito por García-Ríos (2010).

Los ejemplares tipo fueron depositados en el Museo de Zoología Estatal de Munich (Zoologische Staatssammlung Manchen, ZSM), Alemania y en la Colección Biológica de la Universidad de Puerto Rico en Humacao (CBUPRH).

Sistemática: Según la clasificación de Kaas \& Van Belle (1998):

Clase POLYPLACOPHORA (Gray 1821)

Orden NEOLORICATA (Bergenhayn 1955)

Suborden ISCHNOCHITONINA (Bergenhayn 1930

Familia ISCHNOCHITONIDAE (Dall 1889)

Subfamilia LEPIDOCHITONINAE (Iredale 1914)

Género Lepidochitona (Gray 1821)

Subgénero Lepidochitona s.s.

\section{Lepidochitona (L.) bullocki}

(García-Ríos), sp. nov.

(Fig. 1-9)

\section{MATERIAL EXAMINADO}

Holotipo: ZSM Moll 20100542: Ejemplar completo, aplanado, preservado en etanol, $5.5 \mathrm{~mm}$ de longitud. Colombia, Santa Marta,

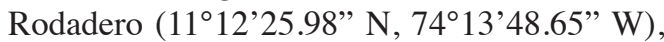
infralitoral somero, entre 0.25 y $1 \mathrm{~m}$ profundidad, a $2 \mathrm{~m}$ de la orilla, sobre roca plana cubierta por algas y sedimentos finos, recolectado por el autor el 12 de octubre de 2009.

Paratipos: ZSM Moll 20100570: Ejemplar completo, aplanado, preservado en etanol, $6.4 \mathrm{~mm}$ de longitud, Colombia, Santa Marta, Rodadero (11¹2'27.25” N, 74¹3'47.28” W), infralitoral somero, entre 0.25 y $0.75 \mathrm{~m}$ profundidad, entre 1 y $2 \mathrm{~m}$ de la orilla, sobre roca cubierta por algas y sedimentos, recolectado por M. Álvarez-Ruiz, L.S. Triana, S.A. Rodríguez, P.C. Tigreros y C.I. García-Ríos, 8 octubre 2009. CBUPRH \#2768: Ejemplar completo, preservado en etanol, $6.5 \mathrm{~mm}$ de 
longitud. La misma localidad y hábitat que el holotipo. CBUPRH \#2770: $4.1 \mathrm{~mm}$ longitud (incluyendo el cinturón), la misma localidad e información de recolección que el holotipo, desarticulado. CBUPRH \#2779: Ejemplar completo, preservado en etanol, $5.5 \mathrm{~mm}$ de longitud, la misma localidad, hábitat e información de recolección que el ejemplar anterior. CBUPUR \#2783: Ejemplar completo, preservado en etanol, $6.2 \mathrm{~mm}$ de longitud, Colombia,

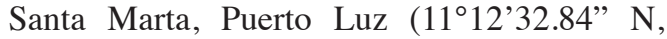
$74^{\circ} 14^{\prime} 1.15^{\prime \prime} \mathrm{W}$ ), infralitoral somero, entre 0.5 y $1.5 \mathrm{~m}$ profundidad, entre 3 a $4 \mathrm{~m}$ de la orilla, bajo roca posada sobre fondo arenoso, recolectado por M. Álvarez-Ruiz y C.I. García-Ríos, 9 de octubre de 2009. CBUPRH \#2785: Ejemplar completo, preservado en etanol, 7.3mm de longitud, Colombia, Santa Marta, Puerto Luz (11 ${ }^{\circ} 12$ '29.84' N, $74^{\circ} 13^{\prime} 54.47^{\prime}$ ' W), infralitoral somero, entre 0.3 y $1 \mathrm{~m}$ profundidad, entre 3 y $5 \mathrm{~m}$ de la orilla, sobre roca posada sobre el fondo, cubiertas por algas y sedimentos, recolectado por M. Álvarez-Ruiz, L.S. Triana, S.A. Rodríguez, P.C. Tigreros y C.I. García-Ríos, 7 de octubre de 2009. CBUPRH \#2787: 6.9mm longitud (incluyendo el cinturón), la misma localidad e información del ejemplar anterior, desarticulado. CBUPRH \#2794: Ejemplar parcialmente enrollado, $1.8 \mathrm{~mm}$ de ancho valva IV, misma localidad e información que el CBUPRH \#2785, desarticulado. CBUPRH 2797: $5.6 \mathrm{~mm}$ de longitud, misma localidad e información que el CBUPRH \#2785, desarticulado.

\section{ENGLISH DESCRIPTION OF THE NEW TAXON}

Animal of small size, holotype $5.5 \mathrm{~mm}$ total length (Fig. 1), bigger paratype $7.3 \mathrm{~mm}$ (CBUPRH \#2785). Width of all types are approximately half of the length (average proportion $54 \%, \mathrm{n}=10$ ). Dorsal elevation of plate IV is 0.34 (CBUPRH \#2787 and \#2794); back rounded, not carinated; side slopes lightly convex. Color and markings of tegmentum highly variable. Holotype is orange and cream with dark brown marks in lateral area of intermediate valves and exterior border of the cephalic valve. A pattern of small greenish blue spots is present in both sides of the jugal area in the intermediate and postmucronal area of the anal valve (Fig. 1A). The paratype ZSM Moll 20100570 with majority of valves dark brown, with cream and orange marks, the intermediate valves II and VI cream and orange, with brown marks in both sides of the jugal area, the same zone were all the intermediate valves have small greenish blue spots (Fig. 1B). Other paratypes with the jugal area yellow and cream, with the rest of the tegmentum speckled with brown, dark brown, cream, rose and orange (CBUPRH \#2783, Fig. 2A). Paratype CBUPRH \#2785 with brown cephalic valve dotted with cream, other valves with white jugal area (except in valve IV, that is orange), lateral areas rose, white with brown marks (Fig. 2B). The paratypes CBUPRH \#2787 (Fig. 2C) and \#2797 (Fig. 2D) orange, the first with clear and brown marks, the other uniformly colored, with some brown marks in valves III and VIII. In all the paratypes it is possible to observe (at least in one valve) the greenish blue spots previously mentioned. The girdle of all the specimens shows alternating cream and reddish brown patches (Fig. 1, 2).

Anterior margin of head valve is semicircular (Fig. 3A). Intermediate valves rectangular, the posterior margin concave on both sides of the apex (Fig. 3B). Apex well defined in all the intermediate valves, more prominent in valve II and III. Lateral areas with poor definition, not raised, except in valve II. The anal valve is smaller than the head valve (Fig. 3). The tegmentum of the anal valve is 2.5 times wider than long, with a semicircular posterior edge (approximately half circle); the anterior edge is straight.

Mucro is prominent, anterior, in the first third of the length. The post-mucronal slopes pronounced, initially $70^{\circ}$, last portion $40^{\circ}$ (Fig. 4).

Tegmental surface irregular, with alternation of raised and depressed squarish zones; they become larger and irregular in the central area of the intermediate valves and premucronal area of the anal valve. In the lateral 


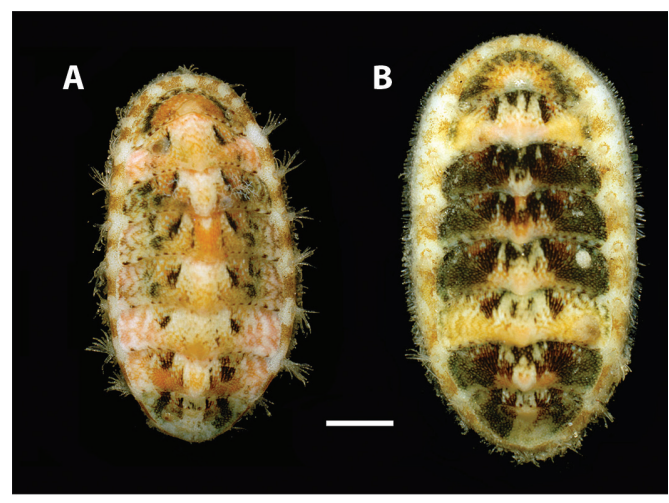

Fig. 1. Lepidochitona bullocki García-Ríos, sp. nov., Vista dorsal de: (A) Holotipo, ZSM Moll 20100542; (B) Paratipo, ZSM Moll 20100570, longitud de la escala = $1 \mathrm{~mm}$.

Fig. 1. Lepidochitona bullocki García-Ríos, sp. nov., dorsal view of: (A) Holotype, ZSM Moll 20100542 ; (B) Paratype, ZSM Moll 20100570, scale bar $=1 \mathrm{~mm}$.

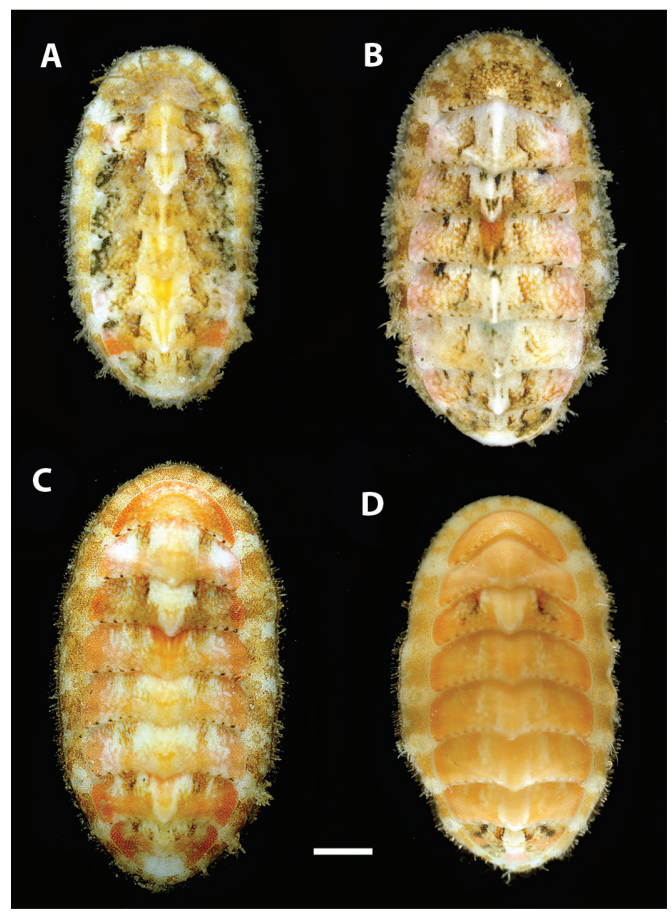

Fig. 2. Lepidochitona bullocki García-Ríos, sp. nov., Vista dorsal de: (A) Paratipo, CBUPRH 2783; (B) Paratipo, CBUPRH 2785; (C) Paratipo, CBUPRH 2787; (D) Paratipo, CBUPRH 2797; longitud de la escala $=1 \mathrm{~mm}$.

Fig. 2. Lepidochitona bullocki García-Ríos, sp. nov., dorsal view of: (A) Paratype, CBUPRH 2783; (B) Paratype, CBUPRH 2785; (C) Paratype, CBUPRH 2787; (D) Paratype, CBUPRH 2797, scale bar $=1 \mathrm{~mm}$.

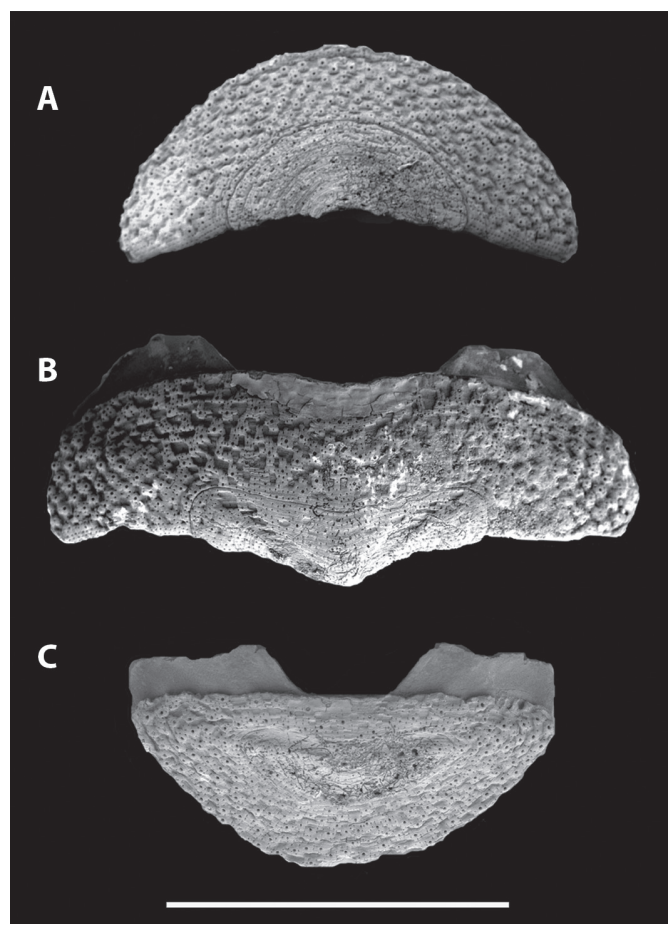

Fig. 3. Lepidochitona bullocki García-Ríos, sp. nov. Longitud total del ejemplar 5.6mm, incluyendo el cinturón, Paratipo CBUPRH \#2794; vista dorsal de: (A) valva cefálica; (B) valva IV; $(C)$ valva anal; longitud de la escala $=1 \mathrm{~mm}$.

Fig. 3. Lepidochitona bullocki García-Ríos, sp. nov Whole specimen 5.6mm long including girdle, Paratype CBUPRH \#2794; dorsal view of: (A)head valve; (B) valve IV; (C) tail valve; scale bar $=1 \mathrm{~mm}$.

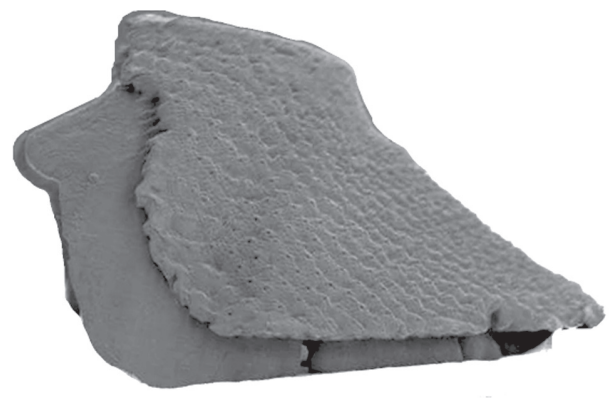

\section{Х4G $5 \mathrm{GG} \mu \mathrm{m}$}

Fig. 4. Lepidochitona bullocki García-Ríos, sp. nov., Paratipo CBUPRH \#2787: vista lateral de la valva anal.

Fig. 4. Lepidochitona bullocki García-Ríos, sp. nov., Paratype CBUPRH \#2787: lateral view of tail valve. 
areas, where the pattern is more regular, the raised squares have sides of approximately $35 \mu \mathrm{m}$ (Fig. 5). In the raised surface are the megaesthetes surrounded by three to seven microesthethes, other microesthethes located in the depressed surfaces (Fig. 6), with an average proportion of eight microesthethes by each megaesthete $(n=4)$. All the esthetes are aligned.

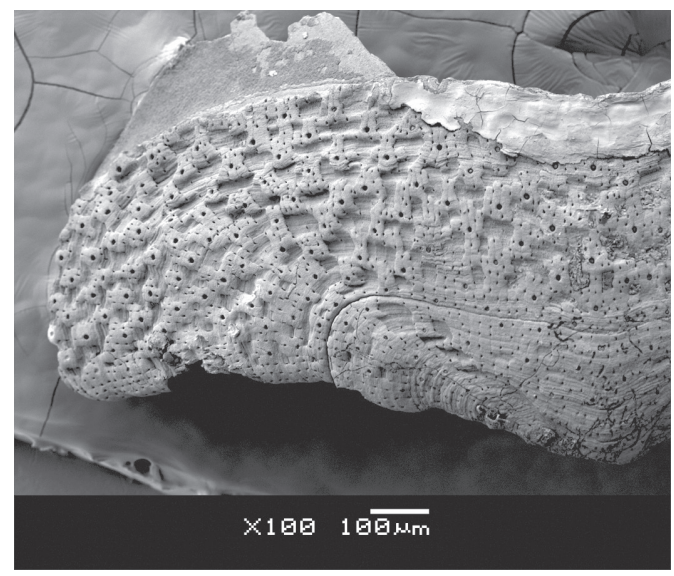

Fig. 5. Lepidochitona bullocki García-Ríos, sp. nov., Paratipo CBUPRH \#2794: detalle del tegumento de la valva IV.

Fig. 5. Lepidochitona bullocki García-Ríos, sp. nov., Paratype CBUPRH \#2794: detail of tegmentum of valve IV.

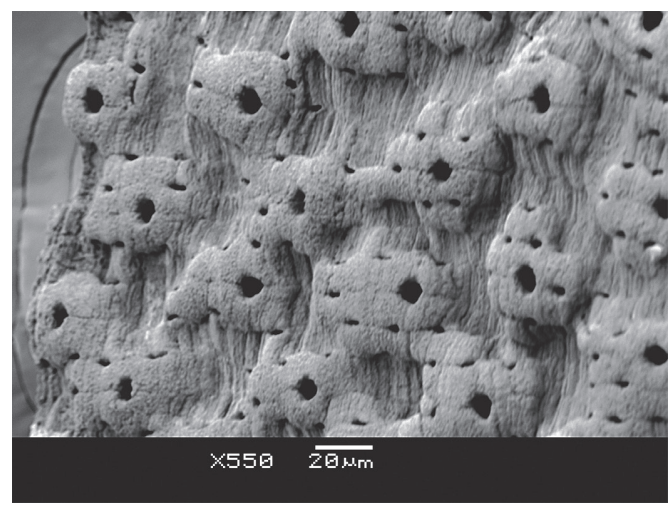

Fig. 6. Lepidochitona bullocki García-Ríos, sp. nov., Paratipo CBUPRH \#2794: Mega y microestetos en área lateral de la valva IV.

Fig. 6. Lepidochitona bullocki García-Ríos, sp. nov., Paratype CBUPRH \#2794: Mega and microesthethes in lateral area of valve IV.
In the lateral zone of the valves the esthetes lines radiate from the apex toward the margins in contact with the belt. As they move away of the apex, some esthetes lines branch off, especially those that are near the lateral line. This maintains the esthetes density almost constant, between 3400 and 4 800/mm² (CBUPR\# \#2770). In the central area of the intermediate valves the esthetes lines are arranged longitudinally, from the previous edge to the lateral line. In the cephalic valve the lines of esthetes radiate from the apex. In the anal shell the esthetes are longitudinally arranged in the antemucronal and radially in the postmucronal (Fig. 4).

Articulamentum is whitish translucent. The insertion plate short, with insertion slit formula 9/1/10 ( $n=3)$. Anal valve of paratype CBUPRH \#2794, has 16 slits with the corresponding 16 slits rays. Apophyses are triangular in valve II, a little less in III, later valves most rectangular, with flattened edges. Apophyses well separated, jugal sinus is ample, approximately a third of the valve width (Fig. 3). The jugal sinus of the intermediate shells is concave, except in the shell II, which is convex.

The dorsal surface of the girdle is covered with colored cylindrical corpuscles, (Fig. 7A).

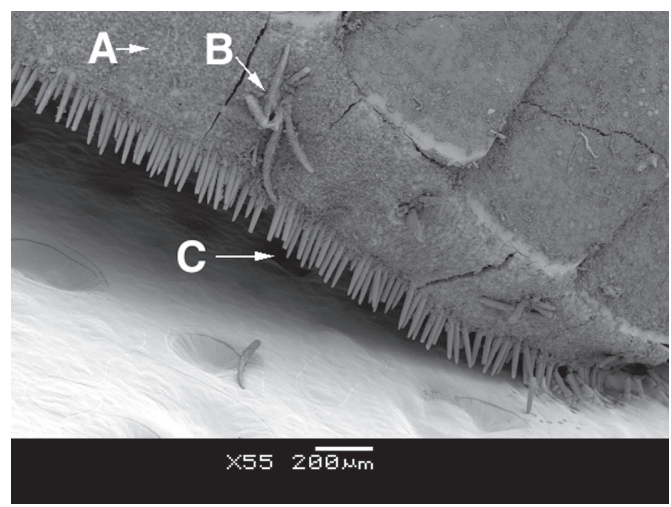

Fig. 7. Lepidochitona bullocki García-Ríos, sp. nov. Longitud total del ejemplar 5.6mm, incluyendo el cinturón, Paratipo CBUPRH \#2797. Dorso del cinturón: (A) cubierta; (B) espículas hialinas; (C) espículas marginales.

Fig. 7. Lepidochitona bullocki García-Ríos, sp. nov. Whole specimen 5.6mm long including girdle, Paratype CBUPRH \#2797. Dorsal side of girdle: (A) cover; (B) hyaline spicules; (C) marginal spicules. 
These corpuscles have 7-9 $\mu \mathrm{m}$ of diameter and 24-35 $\mu \mathrm{m}$ of length (CBUPRH\# 2794). Twenty three (23) tufts of long hyaline spicules are distributed all around the girdle (Fig. 1, 2). Each side of the girdle has seven tufts aligned with the sutures of the valves (Fig. 7B). Another five are on the periphery of the cephalic valve and four near the anal valve. These tufts have an average of 10 spicules, transparent and curved, tightly united in the base. These hyaline spicules can reach $0.5 \mathrm{~mm}$, the anterior ones are shorter or broken. The outer margin of the girdle is surrounded by a row of transparent or amber colored spicules (Fig. 7C, 8A). These marginal spicules measure $120-200 \mu \mathrm{m}$ of length and $15-20 \mu \mathrm{m}$ of diameter in the base. Girdle ventral surface with imbricate transparent spicules, with the pointed ends oriented towards the marginal spicules. These ventral spicules are bigger near the margin, with $50 \mu \mathrm{m}$ of length and $10 \mu \mathrm{m}$ of width in the base (Fig. 8C). The ones located near the palial channel measure $15 \mu \mathrm{m}$ of length. Between the ventral and the

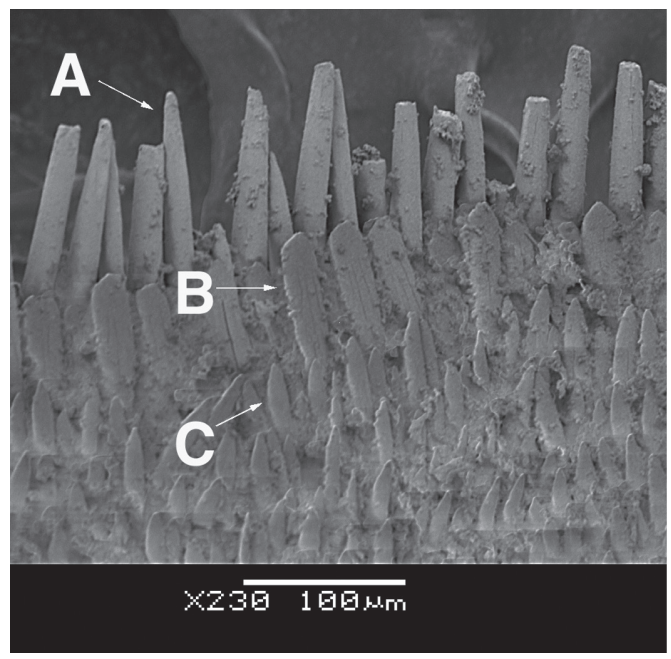

Fig. 8. Lepidochitona bullocki García-Ríos, sp. nov. Longitud total del ejemplar 5.6mm, incluyendo el cinturón, Paratipo CBUPRH \#2797. Vista ventral del cinturón: (A) espículas marginales; (B) espículas submarginales; (C) espículas ventrales.

Fig. 8. Lepidochitona bullocki García-Ríos, sp. nov. Whole specimen $5.6 \mathrm{~mm}$ long including girdle, Paratype CBUPRH \#2797. Ventral view of girdle: (A) marginal spicules; (B) submarginal spicules; (C) ventral spicules. marginal spicules there is a row of submarginal scales, semirectangular, of $80 \mu \mathrm{m}$ of length and $20 \mu \mathrm{m}$ of width (Fig. 8B).

Radulae measure one third of the specimen's length, comprising between 26 to 31 rows of mature teeth and the major lateral teeth mineralized, another 8 to 11 rows of teeth in formation. Central tooth $15 \mu \mathrm{m}$ wide at anterior blade, bend near the edge (Fig. 9A). Major lateral teeth with tricuspid head, 30-35 $\mu \mathrm{m}$ wide, the central denticle a little longer (Fig. 9B). The espatulate unicinal teeth with denticulated blade inwardly curved (Fig. 9C).

There are 13 pairs of gills in the holotype, 11 to 12 in the paratypes. Gills merobranquial, increase of size towards the later end (abanal).

\section{Descripción de la especie}

Animal pequeño, holotipo mide $5.5 \mathrm{~mm}$ de longitud total (Fig. 1), paratipo mayor $7.3 \mathrm{~mm}$ (CBUPRH \#2785). El ancho de todos los ejemplares tipo es un poco mayor que la mitad de su longitud (proporción promedio $=54 \%$, $\mathrm{n}=10$ ). La elevación dorsal de la valva IV es de 0.34 (ejemplares CBUPRH \#2787 y \#2794); dorsalmente redondeada, sin quilla en la región del yugo, pendiente lateral ligeramente convexa. El tegumento muestra colores variados

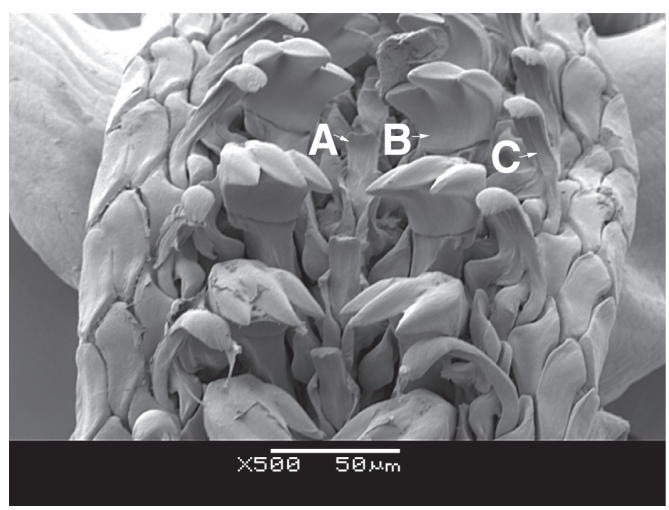

Fig. 9. Lepidochitona bullocki García-Ríos, sp. nov., Paratipo CBUPRH \#2797: rádula: (A) diente central; (B) diente lateral mayor; (C) diente unicino espatulado.

Fig. 9. Lepidochitona bullocki García-Ríos, sp. nov. Paratype CBUPRH \#2797: radula: (A) central tooth; (B) major lateral tooth; (C) spatulate uncinal tooth. 
en patrones diversos. El holotipo tiene color anaranjado y crema con marcas marrón oscuro en las áreas laterales de las valvas intermedias y el borde exterior de la valva cefálica. Presenta un patrón de puntos azul verdoso a ambos lados del área yugal de las valvas intermedias y el área post mucrón de la valva anal (Fig. 1A). El paratipo ZSM Moll 20100570 tiene la mayoría de las valvas color marrón oscuro, con marcas de colores crema y anaranjadas, principalmente en los ápices, las valvas intermedias dos y seis con dominancia de colores crema y anaranjado, con marcas marrón. En todas las valvas intermedias (Fig. 1B) se observan pequeños puntos azul verdosos a ambos lados del área del yugo. Otros paratipos con zona yugal amarilla y crema y el tegumento restante variegado con marrón claro, marrón oscuro, crema, rosado y anaranjado (CBUPRH \#2783). Otro paratipo (CBUPRH \#2785) con valva cefálica marrón, punteada con crema y las demás valvas con área yugal blanca (excepto en la valva cuatro que es anaranjada) y las áreas laterales al área yugal, rosadas y blancas con marcas marrón. Los paratipos CBUPRH \#2787 y 2797 con tonos más anaranjados, mostrando patrones de marcas claras y marrones en el primero y una coloración más enteriza en último, con excepción de marcas marrones en las valvas III y VIII. En todos los paratipos se pueden observar, por lo menos en una de las valvas los puntos azul verdosos antes mencionados. El cinturón de todos los tipos está coloreado con bandas alternas de marrón rojizo y crema (Fig. 1,2).

Valva cefálica con el borde anterior semicircular (Fig. 3A). Valvas intermedias rectangulares, con el margen posterior cóncavo a ambos lados del ápice (Fig. 3B). Ápice bien definido en todas las valvas intermedias, más prominente en las valvas II y III. Las áreas laterales no están bien definidas ni elevadas, excepto en la valva II. Valva anal $7 \%$ más estrecha que la cefálica (Fig. 3) y presenta tegumento 2.5 veces más ancho que largo, así como un borde posterior semicircular (aproximadamente medio círculo) y el borde anterior recto. El mucrón es prominente, localizado anteriormente. La pendiente postmucronal pronunciada, inicialmente de $70^{\circ}$, última porción de $40^{\circ}$ (Fig. 4).

Superficie del tegumento irregular, con alternancia de zonas levantadas y deprimidas de formas cuasicuadradas; que se hacen más grandes e irregulares en el área central de las valvas intermedias y el área premucronal de la valva anal. En las áreas laterales, donde el patrón es más regular, los cuadros levantados tienen lados de aproximadamente $35 \mu \mathrm{m}$ (Fig. 5). En la superficie levantada se encuentran los megaestetos rodeados por tres a siete microestetos, otros microestetos se encuentran en la región deprimida de la superficie (Fig. 6). Se encontró una razón promedio de ocho microestetos por cada megaesteto $(n=4)$.Todos los estetos están en arreglos lineales. En la zona lateral de las valvas las líneas de estetos radian del ápice a los márgenes en contacto con el cinturón. En la medida en que se alejan del ápice, algunas líneas de estetos bifurcan para dar origen a otras, especialmente las que están cerca de la línea lateral. Esto mantiene casi constante la densidad de estetos en toda la superficie, que está entre los 3400 y los 4 800/mm² (CBUPR\# \#2770). En el área central de las valvas intermedias las líneas de estetos están alineadas longitudinalmente, desde el borde anterior hasta la línea lateral. En la valva cefálica las líneas de estetos irradian del ápice. En el área premucrón de la valva anal los estetos tienen arreglo longitudinal y radial en la postmucronal (Fig. 4).

Articulamento blanquecino, algo transparente. Placa de inserción corta, con fórmula de hendiduras de inserción de 9/1/10 (n=3). La placa de inserción de la valva anal del ejemplar CBUPRH \#2794 tiene 16 hendiduras con sus correspondientes radios. Apófisis más triangular y puntiagudo en la valva II, un poco menos en la III, más rectangulares y con bordes más aplanados en las valvas posteriores. Apófisis se encuentran bien separadas, dejan un amplio seno del yugo de aproximadamente un tercio del ancho de la valva (Fig. 3). Seno del yugo de las valvas intermedias es cóncavo, excepto en la valva II, que es convexo. 
La superficie dorsal del cinturón está cubierta por corpúsculos cilíndricos coloreados (Fig. 7A). Estos corpúsculos tienen 7-9 $\mu \mathrm{m}$ diámetro y 24-35 $\mu \mathrm{m}$ de longitud (CBUPRH\# 2794). Alrededor del cinturón se distribuyen 23 mechones de espículas hialinas (Fig. 1,2), siete a cada lado, alineados con las suturas de las valvas, a media distancia entre el tegumento y el margen exterior del cinturón (Fig. 7B). Otros cinco en la periferia de la valva cefálica y alrededor de cuatro cercanos a la valva anal. Estos mechones tienen en promedio 10 espículas transparentes y curvas, unidas en la base. Estas espículas hialinas pueden alcanzar los $0.5 \mathrm{~mm}$, las que están en los mechones anteriores tienden a ser más cortas, o estar partidas. El margen exterior del cinturón está rodeado de una fila de espículas transparentes o con un tinte color ámbar (Fig. 7C, 8A). Estas espículas marginales miden entre 120 y $200 \mu \mathrm{m}$ de longitud y de 15 a $20 \mu \mathrm{m}$ de diámetro en la base. En el lado ventral el cinturón está cubierto de espículas transparentes, solapadas, con las puntas orientadas hacia las espículas marginales. Las más cercanas al margen son más grandes, con longitudes hasta los $50 \mu \mathrm{m}$ y unos $10 \mu \mathrm{m}$ de ancho en la base (Fig. 8C), las localizadas cerca del canal palial miden unos $15 \mu \mathrm{m}$ de largo. Entre las espículas ventrales y las marginales se encuentra una fila de escamas submarginales, semirectangulares, de unos $80 \mu \mathrm{m}$ de longitud y $20 \mu \mathrm{m}$ de ancho (Fig. 8B).

La rádula extendida mide una tercera parte de la longitud total del ejemplar. Tiene entre 26 a 31 filas de dientes formados con los dientes laterales mayores mineralizados y otras ocho a 11 filas de dientes en formación. El diente central tiene $15 \mu \mathrm{m}$ de ancho y un doblez cerca del filo (Fig 9A). Diente lateral mayor tricúspide, mide $30-35 \mu \mathrm{m}$ de ancho, la cúspide central un poco más larga (Fig. 9B). Los dientes unicinos espatulados tienen su extremo distal curvo y denticulado (Fig. 9C).

En el holotipo hay 13 pares de branquias, mientras que en los paratipos hay de 11 a 12 pares. Las branquias con arreglo merobranquial y aumentan de tamaño hacia el extremo posterior (abanal).
Etimología: Esta especie está dedicada al Dr. Robert C. Bullock, autor de múltiples monografías sobre la sistemática de los quitones, con énfasis en los quitones del Caribe. Es el primer investigador en llamar la atención sobre la presencia de otras especies de lepidoquitones en el sur del Caribe, incluyendo, muy probablemente, la que describimos aquí en su nombre.

\section{DISCUSIÓN}

Esta especie es similar a las otras en el género Lepidochitona presentes en el Caribe, tanto en la macromorfología de las valvas, como en el arreglo de las branquias y los elementos que recubren el cinturón. La característica externa distintiva de esta especie es la presencia de densos mechones de largas espículas en el dorso del cinturón. Estas espículas no son ramificadas, como en el subgénero Dendrochiton Berry, 1911, que tiene distribución en la costa oeste de Norte América (Kaas \& VanBelle 1985). La presencia de una sola hendidura a cada lado de las valvas intermedias separa a esta especie de las del subgénero Spongioradsia Pilsbry 1894. La clasificación de $L$. bullocki en el subgénero Lepidochitona se hace considerando la afinidad morfológica y geográfica con las otras especies del género, a pesar de que sus espículas hialinas no son reducidas, como se establece para el subgénero en Kaas \& VanBelle (1985). Esa diferencia menor no justifica la propuesta de un nuevo subgénero.

Lepidochitona bullocki es una especie policromática. Existen ejemplares con coloración similar en otras especies del Caribe. Además de la mayor cantidad y longitud de los mechones de espículas en el cinturón, se puede distinguir a L. bullocki de L. liozonis por la longitud de las espículas marginales. Estas espículas son mayores de $100 \mu \mathrm{m}$ en $L$. bullocki, mientras que en L. liozonis tienen longitudes cercanas a los

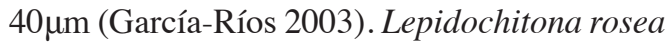
tiene espículas marginales de $130 \mu \mathrm{m}$, pero en el dorso de su cinturón se encuentran sólo unas pocas espinas curvas, de hasta $180 \mu \mathrm{m}$ (Kaas 1972, Kaas \& VanBelle 1985). 
Las irregularidades en la superficie del tegumento de L. bullocki también la distingue de L. liozonis y de L. rosea, que tienen superficies casi lisas (García-Ríos 2010, Bullock et al. 1994). L. rufoi tiene la superficie de su tegumento microgranular, con gránulos redondeados con un megaesteto solitario en el extremo más alto del gránulo (García-Ríos 2010). En contraste, la escultura de la superficie del tegumento de L. bullocki es subcuadrada, con un megaesteto acompañado de varios microestetos en las regiones elevadas (Fig. 6).

El número de hendiduras en la placa de inserción de las valvas ha dejado de usarse como un criterio para discriminar especies (Eernise et al. 2007). Ferreira (1985) advierte de la variabilidad de este número al examinar lotes de Choneplax lata (Guilding, 1829), encontrando de tres a cinco en la valva cefálica, una a ninguna en las intermedias y dos a ninguna en la anal. De los cuatro paratipos desarticulados, tres tienen 10 hendiduras en la valva anal y uno tiene 16, confirmándose la variabilidad de esta característica.

La rádula de L. bullocki (Fig. 9) difiere notablemente de la de L. rufoi en el ancho del diente central, que es seis veces más ancho que el ilustrado para L. rufoi (García-Ríos 2010). El diente lateral mayor de L. liozonis es tricúspide, con cúspides de longitudes similares (GarcíaRíos 2003, Kaas \& VanBelle 1985) mientras que en L. bullocki, la cúspide central del diente es más larga. Esa forma del diente lateral mayor es típica en el género, a juzgar por las ilustradas en Kaas \& VanBelle (1985), donde 17 de las 20 ilustraciones de este diente en lepidoquitones muestran la cúspide central más larga.

La mayoría de los quitones del sublitoral exhiben fototaxia negativa, encontrándose en la parte sombreada de las rocas, muchas veces en el extremo enterrado. Los ejemplares tipo de L. bullocki fueron encontrados en la superficie de las rocas expuestas a la luz, cubiertas por una alfombra de algas y los sedimentos finos que se adhieren a los mucílagos de las algas. Este es un hábitat muy difícil de examinar, si las rocas no están sueltas. Cuando las rocas presentan en esa superficie iluminada grietas o desniveles alargados, podemos encontrar ahí, con mayor frecuencia que los lepidoquitones, a Acanthochitona balesae, un quitón pequeño y vermiforme que se adapta a esos refugios alargados. La especie Lepidochitona sp. B en Bullock \& Franz (1994) y Lepidochitona sp. en Bullock et al. (1994) presenta similitudes en coloración, hábitat y la asociación con A. balesae. Bullock \& Franz (1994) mencionan que encontraron los ejemplares en la zona donde rompe la ola. Esto podría explicar la omisión de los mechones de largas espículas hialinas, pues estas podrían romperse en ambientes de mucha energía. Los ejemplares tipos que usamos en esta descripción fueron recolectados en litoral rocoso con oleaje de baja energía.

\section{AGRADECIMIENTOS}

Agradezco a Migdalia Álvarez Ruiz de la Universidad de Puerto Rico en Ponce y a los colegas del Programa de Biología Marina de la Universidad de Bogotá, Jorge Tadeo Lozano, Sede de Santa Marta, por su asistencia en el campo, en especial a Paulo C. Tigreros, Lina S. Triana y Simón A. Rodríguez. Agradezco la información de posibles estaciones de recolección y el acceso a las primeras fotos y especímenes de esta especie a María F. Gracia y Néstor E. Ardilla. Una licencia sabática otorgada por la Universidad de Puerto Rico en Humacao me permitió completar este manuscrito. El microscopio electrónico de barrido fue prestado por el Programa Partnership for Research \& Education in Materials (PREM) de la Universidad de Puerto Rico-Humacao (NSF-DMR-0934195). Agradezco las críticas y correcciones al manuscrito de Edgardo A. R. Ortiz Corps, Edwin Traverso Avilés, Ariel Díaz Pérez, María Ramos Santiago, José O. Sotero Esteva y cuatro revisores anónimos.

\section{RESUMEN}

El género Lepidochitona (Gray 1821) se encuentra representado en el Caribe por tres especies: L. liozonis (Dall \& Simpson 1901), L. rosea (Kaas 1972) y L. rufoi. Veinte ejemplares de $L$. bullocki sp. nov. fueron 
recolectados en un recorrido a lo largo del litoral rocoso, entre el norte de la playa del Rodadero y Puerto Luz, en Santa Marta, Colombia. Los ejemplares son pequeños, hasta $7.3 \mathrm{~mm}$, fueron recolectados a mano, entre $0.25 \mathrm{y}$ $1.5 \mathrm{~m}$ de profundidad, a distancias entre 1 y $5 \mathrm{~m}$ de la orilla. Esta es la cuarta especie del género que se describe para el Caribe. Las tres especies previamente descritas son $L$. liozonis (Dall \& Simpson, 1901), L. rosea Kaas, 1972 y L. rufoi García-Ríos, 2010. L. bullocki se diferencia de $L$. liozonis y L. rosea por tener la superficie del tegumento irregular y de otros colores. La misma se distingue de $L$. rufoi por tener muchas espículas hialinas largas, mayor tamaño, dientes centrales de la rádula anchos. Es la única especie del género en el Caribe que se localiza con mayor frecuencia en la superficie iluminada de las rocas, en el sublitoral somero.

Palabras clave: Mollusca, Polyplacophora, Ischnochitonidae, Lepidochitona, Caribe, Colombia, especie nueva.

\section{REFERENCIAS}

Bullock, R.C. 1985. The Stenoplax limaciformis (Sowerby 1832) species complex in the New World (Mollusca: Polyplacophora: Ischnochitonidae). The Veliger 27: 291-307.

Bullock, R.C. \& C.J. Franz. 1994. A preliminary taxonomic survey of the chitons (Mollusca: Polyplacophora) of Isla Margarita. Nueva Esparta, Venezuela. Boletín Sociedad de Ciencias Naturales La Salle 54: 9-49.

Bullock, R.C., C.J. Franz \& J. Buitrago. 1994. A report on a collection of chitons (Mollusca: Polyplacophora) dredged near Isla Coche, Nueva Esparta, Venezuela. Sociedad de Ciencias Naturales La Salle 54: 77-93.

Eernisse, D.J., R.N. Clark \& A. Draeger. 2007. Polyplacophora, p. 701-713. In J.T. Carlton (ed.). Light and
Smith Manual: The intertidal invertebrates of Central California to Oregon. University of California, Berkeley, California, EEUU.

Ferreira, A.J. 1985. Chiton (Mollusca: Polyplacophora) fauna of Barbados, West Indies, with the description of a new species. Bull. Mar. Sci. 36: 189-219.

García-Ríos, C.I. 2003. Los quitones de Puerto Rico. Isla Negra, San Juan, Puerto Rico.

García-Ríos, C.I. 2010. Nueva especie del quitón Lepidochitona (Polyplacophora: Ischnochitonidae) de Puerto Rico. Rev. Biol. Trop. 58: 635-644.

Gracia A., J.M. Díaz \& N.E. Ardila. 2005. Quitones (Mollusca: Polyplacophora) del Mar Caribe Colombiano. Biota Colombiana 6: 117-125.

Lyons, W.G. 1988. A review of Caribbean Acanthochitonidae (Mollusca: Polyplacophora) with descriptions of six new species of Acanthochitona (Gray 1821). Am. Malac. Bull. 6: 79-114.

Kaas, P. 1972. Polyplacophora of the Caribbean region. Stud. Fauna Curaçao 41: 1-162.

Kaas, P. \& R.A. Van Belle. 1985. Monograph of living chitons (Mollusca: Polyplacophora).Vol. 2. Suborder Ischnochitonina: Ischnochitonidae: Schizoplacinae, Callochitoninae and Lepidochitoninae. E.J. Brill, Leiden, Holanda.

Kaas, P. \& R.A. Van Belle. 1998. Catalogue of living chitons (Mollusca: Polyplacophora). Backhuys, Leiden, Holanda.

Smithe, F.B. 1975. Naturalist's color guide. The American Museum of Natural History, Nueva York, EEUU. 